\title{
The Concept of Discretionary Penalty and Compensation and Its Implementation in the Fatwas of National Sharia Board-Indonesian Ulema Council
}

\author{
Panji Adam \\ Faculty of Sharia \\ Universitas Islam Bandung \\ Bandung, Indonesia \\ panjiadam06@gmail.com \\ Ira Siti Rohmah Maulida \\ Faculty of Sharia \\ Universitas Islam Bandung \\ Bandung, Indonesia
}

\author{
Maman Surahman \\ Faculty of Sharia \\ Universitas Islam Bandung \\ Bandung, Indonesia \\ Akhmad Yusup \\ Faculty of Sharia \\ Universitas Islam Bandung \\ Bandung, Indonesia
}

\begin{abstract}
One of the risks that exist in the financing risks faced by Islamic Financial Institutions, namely the risk of default on the part of the customer in the form of financing. In addition to the way risk management, LKS can also cope with the risk of default by applying ta'zir (discretionary penalty) and ta'wîdh (compensation). Juridical basis of existence and ta'wîdh ta'zir concept is in the form of National Sharia Board fatwa-Indonesian Ulema Council (DSN-MUI). This article analizes implementation of fatwas of DSN-MUI in relation to ta'zir and ta'widh.
\end{abstract}

Keywords; Ta'zir, Ta'wîdh, National Sharia Board, Fatwa, Indonesian Ulema Council

\section{INTRODUCTION}

Islamic financial institutions (LKS) in Indonesia has grown rapidly, this led to many parties want to know what the fundamental difference between Islamic Financial Institutions with Conventional Financial Institutions. One distinction that is often put forward by the experts is that in Islamic Financial Institutions must exist Underlying Transaction obvious, so money should not be profitable on its own, without any pedestal transactions, such as buying and selling that lead to margins, lease would generate fees and attaching capital will earn a share (profit and loss sharing). In other words, the difference between Islamic Financial Institutions with Conventional Financial Institutions lies in the contract or transaction [1].

Akad has an important role in the transaction. The jurists 'when introducing the concept of contract of course by relying on arguments of Sharia (al-ruju' ila al-Qur'ân wa al-Sunnah) to determine its validity. The purpose of the contract is that the values of sharia is behind the contract, namely the certainty of the form of the transaction can be achieved, thus avoiding the manipulative transaction practices.

At first, the contract (akad) is only used for transactions between individuals. However, in the development, the concept of contract is widely used to develop a wide range of financial products / business Sharia involving institutions and corporate institutions.
One form of financing transactions to its customers LKS is financing in the financing or channeled funds to customers, either through a sale and purchase agreement, lease or partnership contract. One of the financing transactions undertaken in LKS both banks and non-banks are reimbursing transaction with the sale and purchase agreement, more specifically is selling murabaha.

In the transaction using murabaha sale and purchase agreement in addition to LKS own profit, or pecuniary benefit margin, LKS was not free of risk, how many default actions performed by the customer. One can anticipate the risks arising from the default is to apply the ta'zir (a late fee for customers who are negligent) and ta'wîdh (compensation due to losses incurred by LKS).

National Sharia Council (DSN) as an institution that has the authority to issue fatwas in the field of Islamic economics have a significant role in operational transactions conducted LSK. DSN-MUI (National Sharia Board-Council of Ulema Indonesia) as an Islamic fatwa institution in the field of economy to mid-2018 has issued a fatwa 122 related to finance / business Sharia. In fact, from the fatwas of DSNMUI, not least that adopting the concept of a contract to serve as the basis of the transaction (underlying transaction) so that its validity is legitimate. One of the fatwas relating to transactions carried out by LKS is a fatwa on ta'zir and ta'wîdh

The purpose of this paper is (1) to determine ta'zir concept and its implementation in the DSN-MUI fatwa; (2) to determine the ta'wîdh concept and its implementation in the DSN-MUI fatwa.

\section{RESEARCH METHOD}

This study uses normative juridical approach, namely by reviewing or analyzing secondary data such as ingredients secondary law to understand law as a set of rules or norms positive in the legislation in force, so this study is understood as the research literature, the study of materials secondary (Soerjono Soekanto \& Sri Mamudji, 1985, 15). The reason of 
this research using normative juridical approach is because this study used secondary data aims to analyze secondary data in the form of legislation in accordance with the focus of this study.

The nature of this research is descriptive analytical research, ie research to illustrate the problems that exist at the present time (actual problems), to collect data, organize, classify, analyze, and interpret. Descriptive aimed explain the observed data without testing the hypotheses (Rianto Adi, 2004, 130).

Therefore, this study classified normative juridical research, the necessary data is secondary data. The primary data in this study by interviewing only as an amplifier and an additional course. Secondary data that is needed is the primary legal materials sourced from primary sources, ie literature in the form of books of fiqh and the National Sharia Board Fatwa Council of Ulama Indonesia. In addition to primary legal materials are also required secondary law derived from secondary data, ie books or books (fiqh, hadith, hadith and tafsir commentary) and other legal writings relevant to the formulation of the problem. Also required tertiary legal materials, such as dictionaries and encyclopedias both legal and common in Arabic, English and Indonesian.

Based on the type of data that will be used in this research is secondary data which are qualitative, then, the data collection techniques that will be achieved is by way of a literature study. To obtain the necessary data in this study used an instrument and method as follows. In terms of studying secondary data materials, first; learning the rules of legislation that became the object of research, selected and collected later from ingredients that have principles and rules of law concerning halal certification. After that, the selected framework of the systematically for easy analysis.

The technical data analysis that used in this study is a qualitative method normative. Analysis of secondary data that are qualitative in nature is done in a manner based on the theory of law or legal doctrine contained in the framework, then applied deductively to the identification of problems of this study, which will then be drawn to a conclusion that could answer the problems that matter in this writing.

\section{PREPARE Your PAPER Before StYling}

\section{A. Ta'zir concept and its implementation in the DSN-MUI}

In the concept of jurisprudence, studies on ta'zir in the realm of jurisprudence jinayah (Islamic criminal law), but in the development of the concept of ta'zir included as part of the discussion of jurisprudence muamalah.

Ta'zir is a form of the word mashdar عزر-يعزر which etymologically means الرد والمنع, which means rejecting and preventing [2]. The sanctions of ta'zir are imposed to perpetrators jarimah (criminal offense) who commits an offense, both with regard to the rights of God and of human rights, and not fall into the category hudûd punishment or expiation, because ta'zir not determined directly by the Qur'an and Sunnah, then this becomes the competence of local authorities. In deciding the type and size ta'zir sanctions, must consider carefully the instructions nash as it concerns the common good.

In connection with financial transactions, the legal basis for determining ta'zir sanctions are actions that should be avoided, that is injustice (zhulm) and inattentive / trespassers (al'ta'adi). This refers to the words of Allah's Apostle Saw as follows:

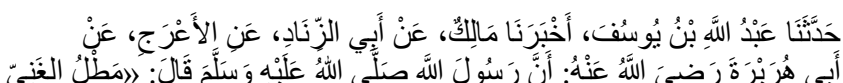

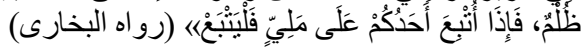

"It has told us Abdullah Ibn Yusuf, has been reported to us Malik, from Abi Abi al-Zinad of al'Araj, from Abi Hurarirah ra, that the Prophet Muhammad said:" The rich (who are able to pay the debt) who delays the debt is an unjust act, and when the (debt), one of you be transferred to those who are able to let him receive it "(Bukhari).

In the implementation, the concept of jurisprudence muamalah, ta'zir sanctions usually penalties (al-ghuramah; al'uqubah al-Maliyah). Penalties (al-ghuramah; al-'uqubah alMaliyah) is the result of ijtihadi. Therefore, there are scholars who allow and some are forbidden (deviation). According to Muhammad Zuhaili [3], there are differences in opinion among the scholars regarding sanctions ta'zir in the form of fines, as follows: first, Imam Abu Yusuf (follower and disciple of Imam Hanifa Ahu) allows for sanctions in the form of material ta'zir (al-ghuramah; al-'uqubah al- Maliyah), for example fines; second, jumhur (majority) of the clergy banned for fear of falling to usury or taking property of others unjustly because it is not right.

Opinions Abu Yusuf that allow sanctions / fines ta'zir received support from other scholars. Among the arguments used is the hadith of the Prophet as follows:

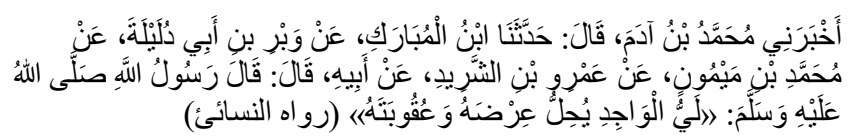

"It has been reported to us Muhammad Ibn Adam, he said, had told us Ibn al-Mubarak, from Ibn Abi Wabri Dulailah, from Muhammad Ibn Maymun of Ma'mar Ibn al-Syadir of his father, he said, the Prophet said: people unable to pay debts but postpone, postpone the pertinent lawful self-esteem and lawful sanctions ". (Reported by al-Nasa'i).

According to Rafiq Yunus in his book al-fiqh al-Maliyah Mu'amalah explain argument permissibility of penalties (alghuramah; al-'uqubah al-Maliyah), which are analogous to the laws of charity. Parties who refused to pay zakat should be penalized in a way taken (by force) half of his possessions [4].

DSN-MUI Fatwa Relating to ta'zir is National Sharia Board Fatwa No: 17 / DSM-MUI / Ix / 2000 On Top sanctions Able Customers who delay payment.

According Jaih Mubarok, there is a sociological considerations in setting the fatwa related to ta'zir, that is National Sharia Board Fatwa No: 17 / DSM-MUI / Ix / 2000 On Top sanctions Able Customers who delay payment. As for the consideration of sociology in the decree are as follows [5]:

1) Many communities require financing of Islamic Financial Institutions based on the principle of the contract of sale or other payment to the Islamic Financial Institutions is done in installments.

2) Customers were able to sometimes delaying payment obligations, either in the contract of sale or other contract, at a predetermined time based on the agreement between the two sides. 
3) Society, in this case the Islamic Financial Institutions, asked for a fatwa to the National Sharia Council action or sanctions what can be done to clients capable of procrastinating the payment is according to Islamic law.

4) Therefore, the National Sharia Council needs to set a fatwa on sanctions for customers capable who delay the payment according to the principles of Islamic law, to be used as guidelines by Islamic Financial Institutions.

In addition to sociological considerations, the substance / provision contained in the DSN No. 17200 on Sanctions for Customers Able to which Procrastination Payment is [5]:

1) The sanctions mentioned in this fatwa is a sanction imposed Islamic Financial Institutions to customers who can afford to pay, but delaying payments to deliberate.

2) Customers who do not / have not been able to afford due to force majeure should not be penalized.

3) Customers were able procrastinating payment and, or do not have the will and not good to pay its debts may be penalized.

4) Sanctions are based on the principle ta'zir, which aims to enable customers to be more disciplined in carrying out its obligations.

5) Penalties may be fined a sum of money which the number of amount is determined on the basis of an agreement and made when the contract is signed.

6) The funds raised from fines is intended charity.

\section{B. Ta'wîdh concept in its implementation in the DSN-MUI}

In the book of al-Wasit Mu'jam explained that the word ta'wîdh literally comes from the word al-'iwadh meaningful compensation (replacement value). Said al-ta'wîdh equated with the word al-mu'âwadhat which means exchange. In language al-ta'wîdh derived from the word al-badal (substitute) [2]. Iyad Ibn Issaf Maqbal explained that alta'wîdh meaning of the term is an obligation to make a payment in exchange for the cost incurred to overcome certain difficulties [6].

According Bagya Agung Prabowo, ta'wîdh is compensation, fines imposed for violations of the agreement. Violation of the agreement in question is that one party willfully fails to fulfill its obligations has been agreed, causing losses to the other party [7].

Understanding ta'wîdh according to the contemporary scholars differ. Wahbah al-Zuhaili as quoted by Bagya Agung Prabowo stated that ta'wîdh is cover the losses caused by the violation or mistake. ta'wîdh intended to cover the losses can be objects or cash [7].

In practice, the definition of compensation is a fee charged to customers for endeavor undertaken Islamic Financial Institutions in order to cope with financing problems. Costs can arise due to [5]:

1) Correspondence activity, either using electronic devices, media, and mailing.
2) The use of third-party service for collecting or debt collection.

3) The activities carried out by a special unit in charge of Islamic financial institutions find solutions to financing problems.

The provisions concerning the imposition of compensation is that the amount to be charged to the customer should be equal to the amount of funds spent by the Islamic Financial Institutions in the effort to cope with financing problems. Redress the basic principle is to prevent injustice (not harm others and was not harmed others). Therefore, including eating improperly treasure when wearing the Islamic Financial Institutions damages exceed the amount of funds that the issuance; the excess can be classified as usury.

In the DSN-MUI fatwa No. 43 / DSN-MUI / VIII / 2004 on Torts (ta'wîdh) consists of three (3) parts, namely sociological considerations, general provisions and special provisions. Fatwa sociological considerations are:

1) Financial institutions Shari'ah (LKS) operates on the principle of Sharia in order to avoid the practice of usury or practices that lead to usury, including the issue of financial penalties which is usually done by conventional financial institutions;

2) The parties to a transaction in LKS sometimes runs the risk of loss due to default or negligence by delaying payment by the other party in violation of the agreement;

3) Islamic Shariah protects the interests of all parties to a transaction, both the customer as well as worksheets, so there should be no one else injured parties their rights;

4) Losses are actually experienced in real terms by the parties to the transaction shall be replaced by the party causing the loss;

5) Society, in this case the parties to a transaction in LKS asked for a fatwa to the DSN on compensation due to procrastination of payment in a condition capable of;

6) In an effort to protect the parties to a transaction, DSN deems it necessary to set a fatwa on compensation (ta'wîdh) For guidance.

In the first judgment described explicitly that "Islamic Financial Institutions to operate based on Sharia Principles to prevent the practice of usury or practices that lead to usury, including the issue of financial penalties which is usually done by Conventional Financial Institutions". Therefore, in consideration of sociological seen that fines (ta'wîdh) Associated with usury doctrine that should be avoided by Islamic Financial Institutions [5].

In the DSN-MUI fatwa No. 43 / DSN-MUI / VIII / 2004 on Torts (ta'wîdh) have allowed Indemnity (ta'wîdh) as described in the fatwa [8]:

General requirements:

1) Compensation (ta`wîdh) Should only be imposed on the parties intentionally or negligently does something deviate from the provisions of the contract and causing loss on the other hand. 
2) These losses can be charged ta'wîdh referred to in paragraph 1 is the real losses that can be calculated clearly.

3) The real losses referred to in paragraph 2 is that the real costs incurred in the billing rights that should have been paid.

4) Large compensation (ta`wîdh) Is in accordance with the value of the loss of real (real loss), which must be experienced (fixed cost) in such transactions and not the losses expected to occur (potential loss) for their lost opportunities (opportunity loss or al-furshah aldha-i ' Ah).

5) Compensation (ta`wîdh) Should only be applied to a transaction (contract) that give rise to debts (dain), such as greetings, istisnaa well as murabaha and Ijarah.

6) In Mudaraba and Musharaka contract, compensation should only be worn by Shahibul mall or one of the parties in the Musharaka when part of the benefits are obvious but not paid.

Special Conditions:

1) Compensation received in the transaction at LKS can be recognized as a right (income) for those who receive it.

2) The amount of compensation the amount be fixed according to real losses and manner of payment depends on the agreement of the parties.

3) The amount of this compensation should not be specified in the contract.

4) The injured party is responsible for the appointment of court fees and other costs incurred as a result of the settlement process.

In this fatwa needs to be defined is the definition of actual loss operationally. It is also indirectly related to the real costs, real losses (real) as opposed to a loss that is the potential (potential losses).

In general, real losses can arise due to: (1) the cost of correspondence to contact the customer, either by phone, email or correspondence; (2) the cost of the verification conducted by the bank directly; or (3) the cost of the use of services of other parties to enable customers to pay or repay the debt [5].

The legal provisions are based on the following postulates. Opinion Ibn Qudaman in the book al-Mughni Juz IV, p. 342: that the delay in payment obligations can result in losses (dharar) and therefore should be avoided; he stated:

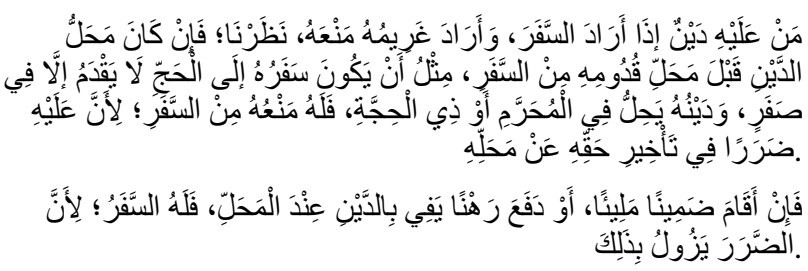

"If people owed (debtors) intend to travel, or if the indebted parties (creditors) intends to prohibit the debtor (travel), we need to consider the following. If it turns out debt maturities before the arrival of, i.e. a trip, traveling to the pilgrimage in which the debtor is still in pilgrimage while debt maturities in the month of Muharram or Dzulhijjah-- then the lender may be forbidden to travel. This is because he (the creditor) will suffer a loss (dharar) due to delays in (gain) right at maturity. However, if the debtor appoint a guarantor or submit a guarantee (qadai) that is sufficient to pay its debts at maturity, he could make the trip, because it gives the creditor losses can be avoided. "

Also the opinion of al-Zuhaili Wahbah in the book of alDhaman Nadziyat mold Darul Fikr Damascus, 1998:

$$
\text { (86) التعويض هو: تغطية الضرر الواقع بالتعدى او الخطا }
$$

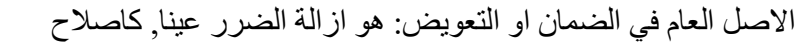

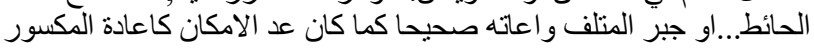
(94) صحيحا, فان تعذر ذلك وجب التعويض المنلى او النقدى التى كاعل

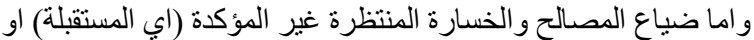

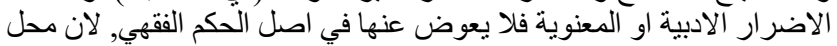

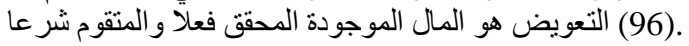

"Ta'wîdh (Compensation) is shut losses arising from violations or errors "(p. 87).

"General provisions on compensation can be:

1) cover losses in the form of objects (dharar, danger), such as repairing the wall ...

2) repairing damaged objects become whole again as before long as possible, such as restore broken objects become whole again. If this is hard to do, then it must replace it with the same object (a type) or with money "(p. 93).

Meanwhile, the loss of profits and losses are uncertain in the future or immaterial damages, then according to the legal provisions of fiqh, it cannot be replaced (requested compensation). That's because the object of compensation is a treasure that exists and concrete as well as valuable (Shari'a permitted to use it "(p. 96).

Opinions 'Abd al-Hamid Mahmud al-Ba'li, Mafaheem Asasiyyah fi al-Bunuk al-Islamiyah, al-Qahirah: al-Ma'had al'Alami li-al-Fikr al-Islami, 1996:

$$
\begin{aligned}
& \text { ضمان المطل مداره على الضرر الحاصل فعلا من جر اء التاجير في لئي }
\end{aligned}
$$

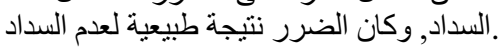

"The compensation for delays in payment by a person who is able to be based on the losses incurred in real terms due to payment delays and losses it is a logical result of the delay in the payment."

Opinion of scholars who allow ta'wîdh as quoted by 'Isham Anas al-Zaftawi, Hukm al-gharamah al-Maliyah fi alFiqh al-Islami, al-Qahirah: al-Ma'had al-'Alami li-al-Fikr alIslami, 1997:

$$
\begin{aligned}
& \text { الضرر يز ال حسب قو اعد الشر عية, و لا از الة الآ بالتعويض, ومعاقبة } \\
& \text { المدين الممطال لا تفيد الدائن المضرور. }
\end{aligned}
$$

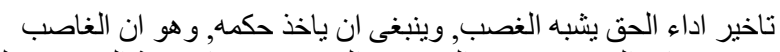

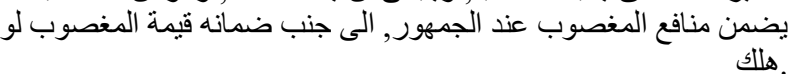

"Losses should be eliminated by the rules of Sharia and losses it will not disappear unless it is replaced; while imposing sanctions on the debtor is able procrastinating 
payment will not provide the benefit for creditors who are disadvantaged.

Delay payment equal rights with ghashab; Therefore, should the legal status is the same, namely that the perpetrators ghashab responsible for the benefits of objects in-ghasab during ghashab, according to the majority of scholars, in addition he had to bear the price (value) of the item when it is broken. ".

\section{CONCLUSION}

Based on the description and explanation in the section above discussion, it can be drawn some conclusions as follows. Ta'zir sanctions are imposed to perpetrators jarimah (criminal offense) who commits an offense, both with regard to the rights of God and of human rights, and not fall into the category hudûd punishment or expiation, because ta'zir not determined directly by the Qur'an and Sunnah, then this becomes the competence of local authorities. DSN-MUI Fatwa Relating to ta'zir isNational Sharia Board Fatwa No: 17 / DSM-MUI / Ix / 2000 On Top sanctions Able Customers who delay payment. Ta'wîdh is compensation, fines imposed for violations of the agreement. Violation of the agreement in question is that one party willfully fails to fulfill its obligations has been agreed, causing losses to the other party. DSN-MUI Fatwa related to compensation or ta'wîdh is DSN-MUI fatwa No. 43 / DSN-MUI / VIII / 2004 on Torts (ta'wîdh).

\section{REFERENCES}

[1] Djamil, Fathurrahman Penerapan Hukum Perjanjian dalam Transaksi di Lembaga Keuangan Syariah, Sinar Grafika, Jakarta, 2012, hlm. V.

[2] Anis, Ibrahim et al. al-Mu'jam al-Wasîth, Majma al-Lughah al'Arabiyyah, Mesir, 1972, hlm. 598.

[3] al-Zuhaili, Muhammad al-Nazhariyat al-Fiqhiyyah, Dâr al-Qalam, Damaskus, 1993, hlm. 66.

[4] al-Mishri, Rafiq Yunus Fiqh al-Mu'âmalah al-Mâliyah, Dâr al-Qalam, Kairo, 2007, hlm. 107

[5] Mubarok, Jaih Fikih Mu'amalah Maliyah: Prinsip-Prinsip Perjanjian, Simbiosa Rekatama Media, Bandung, 2017, hlm. 152.

[6] al-'Inzi, Iyadh Ibn Issaf Maqbal al-Syurûth al-Ta'wîdhiyyah fî alMu'âmalat al-Mâliyah, Dar Kunuz Isybilya, KSA, 2009, Juz. II, hlm. 326

[7] Prabowo, Bagya Agung Aspek Hukum Pembiayaan Murabahah Pada Perbankan Syariah, UII Press, Yogyakarta, 2012, hlm. 69.

[8] Oni Sahroni dan Adiwarman A Karim, Maqashid Bisnis \& keuangan Islam: Sistesis Fikih dan Ekonomi, PT RajaGrafindo Persada, Jakarta, 2015, hlm. 155 